\title{
Efficacy of oil palm intercropping by smallholders. Case study in South-West Cameroon
}

\author{
Yvonne K. Nchanji $\mathbb{D}^{-}$Raymond N. Nkongho • \\ William A. Mala $\cdot$ Patrice Levang
}

Received: 27 February 2015/Accepted: 17 October 2015/Published online: 24 October 2015

(C) The Author(s) 2015. This article is published with open access at Springerlink.com

\begin{abstract}
Intercropping oil palm during its immature stage with food crops is usually blamed for its negative impact on the growth and future yields of palms. Agroindustries unanimously condemn such practice. For smallholders on the contrary, intercropping presents numerous advantages as it not only covers the weeding cost but also provides food and revenue while waiting for the palms to come into production. While such trade-off may be of little interest to an agro-industry, it appears as determining for many smallholders. The study was carried out in seven communities in the Bamuso Sub-division of the South-West Region of Cameroon and seeks to understand how smallholder oil palm farmers (small, medium and large scale) use the intercropping technique during the early stages of oil palm development as a means to improve on their livelihood. Results indicated that, a mean annual wage of 705,000 FCFA ( $€ 1075)$ was obtained per hectare per household for smallholders practicing
\end{abstract}

Y. K. Nchanji $(\varangle) \cdot$ R. N. Nkongho $\cdot$ P. Levang Center for International Forestry Research (CIFOR), P.O BOX 2008, Yaoundé, Cameroon

e-mail: ynchanji@gmail.com

Y. K. Nchanji · W. A. Mala

Department of Plant Biology, University of Yaoundé 1, P.O BOX 775, Yaoundé, Cameroon

\section{P. Levang}

Institut de Recherche pour le Développement (IRD), GRED, Montpellier, France intercropping. In addition to income gained, intercropping significantly reduced the cost of weeding. The study therefore, suggests the need for pre-emptive measures - such as food crop choice, planting density amongst others- to be taken into consideration when intercropping annual food crops with oil palm so as not to jeopardize the yield of oil palm at production stage. The finding is of significance for sustainable agriculture in that intercropping encourages poverty reduction for marginalized people especially women with no access to land, maximises land use by farmers, food security in households, stability in yield and profit in smallholders' oil palm plantations.

Keywords Intercropping - Elais guineensis . Annual food crops · Oil palm smallholders . Monocropping · Sustainable agriculture

\section{Introduction}

The oil palm (Elceis guineensis) originates from the tropical rain forest regions of West Africa with the main belts running through the southern latitudes of Sierra Leone, Liberia, Ivory Coast, Ghana, Nigeria, Cameroon, and into the equatorial regions of Angola and Congo (Kwasi 2002). It belongs to the family Palmae, sub-family Cocoideae, having 225 genera with over 2600 species (Opeke 1987). It is a versatile tree crop with almost all parts of the tree being useful and of economic value (Ibitoye et al. 2011). 
Oil palm can produce high yields when grown under the right biophysical conditions: (i) high temperature all year round, between 25 and $28{ }^{\circ} \mathrm{C}$; (ii) sufficient sunshine: at least $5 \mathrm{~h}$ of sunshine per day; (iii) high precipitation: evenly distributed rainfall 1800-2400 mm/year without dry spells for more than 90 days. Higher rainfall can be tolerated as long as soils are well drained; (iv) soils: prefers rich, free draining soils, but can also adapt to poor soils with adequate use of fertilizers, and; (v) low altitude: ideally below $500 \mathrm{~m}$ a.s.1. (Better Crops International 1999; Jacquemard 2012).

In Cameroon, family agriculture includes producers often referred to as "smallholder ( $\mathrm{SH}$ )" which is a production unit linked to a family structure, with a strong reliance on family labour (San Cortés 2003). Oil palm production in Cameroon is stratified in three sectors: an agro-industrial sector, smallholders ( $\mathrm{SH}$ ) that used to be in contract with agro-industries and a traditional independent artisanal sector (Bakoume et al. 2002).

Following the drop in the early 1990s of the prices of cocoa and coffee which were then the major commercial farming crops in Cameroon, many smallholders turned to planting oil palm (Ngando et al. 2011; Nkongho et al. 2014). This fact is further illustrated by the amount of germinated oil palm seeds purchased by small and medium size farmers at the IRAD-Specialised Center for oil palm research of $\mathrm{La}$ Dibamba (CEREPAH) in Cameroon which rose from $20 \%$ of the total production in 1996 to an average of $60 \%$ in the following years (Ngando et al. 2011). From this data, it is estimated that about 5000 ha of oil palm were planted by small and medium size farmers each year during the last decade, making a total of about 90,000 ha for the non-industrial oil palm area in Cameroon (Bakoume and Mahbob 2006). Oil palm smallholdings have been booming since the mid1990s notably since 1993 with a trebling of planted areas (Rafflegeau and Ndigui 2001).The upsurge has been more in communities around the oil palm agroindustrial corporations of SOCAPALM, CDC and PAMOL Plc.

Despite this increase, the two major factors of production: land and capital still limit the expansion of this activity within smallholder farmers' communities (Nair 1993), particularly the high investment cost to open a new plantation (mainly clearing and seedling cost) and the production cost at the immature stage of oil palm development (Vermeulen and Goad 2006). The length of time (about 3-4 years) needed for the oil palm to start producing is a major problem for the smallholders who have to invest considerable amounts of money and/or labour before deriving income from their oil palm plantations. Smallholder farmers are therefore testing different options such as intercropping oil palm with food crops in order to mitigate these costs (Tonye et al. 2004; Zen et al. 2005). Looking at the aspect of weed control, studies have revealed that intercropping often shades weeds to a greater extent, leading to a reduction in weed density and biomass when compared to monocrops (Liebman and Dyck 1993; Tonye et al. 2004).

Ironically, intercropping is not practiced by most if not all famers because the results of intercropping can be uncertain. Some experiments have shown no or inconsistent yield benefits. Even with proper management, yields of intercrops can be easily influenced by growing conditions. Although growing conditions affect all agricultural systems, there is evidence to suggest that the complexity of intercropping can make that system more vulnerable to environmental stresses. Combined with the greater degree of management skills required to operate this system, yield uncertainty may hamper the adoption of intercropping (Pridham and Entz 2008; Agrobrief No 4 2011). Furthermore, if crop choices or timing differences in crop life cycles are not managed correctly, the two crops can compete with each other for water and nutrient resources with negative yield results (Brainard and Bellinder 2004). There is also the problem of farm maintenance operations which may be difficult to mechanize as enough space must be left for the mobile equipment (Amoah et al. 1995). Another major problem is the denseness of the crops which can make it physically more difficult to combat diseases, pests and weeds. If the crops in association are not well selected, some crops may act as host for transmitting potential pathogens to other crops.

As intercropping is usually considered as negatively impacting yields (Pridham and Entz 2008), very little research has been carried out to study the positive aspects of intercropping as a means to lower the production costs and to help the smallholders to overcome the unproductive stage of oil palm plantations. It is within this framework that this research seeks to address the following question: What are the trade-offs? Can intercropping be used as a means to improve on the livelihood of smallholder oil palm 
farmers without affecting the yield of oil palm at the production stage? More specifically, the study aims at: (i) characterising the different food crops intercropped with oil palm and to investigate the agronomic practices put in place with respect to choice of crop, planting time, and as well as intra- and inter-spacing patterns used during the immature period of the palm; (ii) diagnose the link between intercropping and socioeconomic development of oil palm smallholders; (iii) demonstrate how intercropping can be used as a means to control weeds on oil palm plantations; (iv) compare the agro-ecological and socio-economic advantages of those who practice intercropping as opposed to those not practicing intercropping.

\section{Materials and methods}

Study area

The study was carried out in the Bamuso Sub-division of the South-West Region of Cameroon which is located around the new development area of CDC in the Boa plain. This has triggered the opening of $\mathrm{SH}$ plantations as oil palm seedlings from CDC were readily available. It therefore was much easier to locate $\mathrm{SH}$ with young oil palm plantations. Seven villages in the area (Dikume, Illoani, BarombiMokoko, Bonjare, Ekumbe-Mofako, Mbongo and Ekumbe-Liongo) were selected through purposive sampling. This selection was done based on the predominant production of oil palm per village and this served as the sample size for the zone. Smallholder (SH) oil palm farmers were then randomly selected from the sampled area using a list of all smallholders in the area which was presented by the smallholder oil palm field assistant of CDC. The number of respondents per village selected depended on the number of smallholder farmers in the said village with immature oil palm plantations. In villages with more oil palm smallholder farmers, 10 farmers were randomly sampled and in villages with a fewer number of oil palm farmers, 6 farmers were randomly selected and they served as our sample size.

\section{Data collection}

Smallholders selected were interviewed and questioned on the different activities undertaken on their oil palm plantations. 50 questionnaires were administered to oil palm smallholder farmers (farmers involved in intercropping and those not involved in intercropping) and 5 to CDC personnel-for the primary basis of results follow-up, giving a total of 55 questionnaires. Questions were asked on the general plantation details, source of planting materials, cost of farm setup, etc.

Data analysis

Information obtained from the questionnaires was transmitted into a database for eventual analysis using Microsoft Excel 2010. Descriptive statistics were applied with use of tables, frequencies and charts.

\section{Results}

Identification of smallholder farmers

The personal information provided by respondents (Table 1) indicated a trend of those involved in smallholder oil palm plantations in the study site. More men are involved with oil palm plantations than women in the study area. This is so because women are limited by land tenure and acquisition rights to own land, as well as by capital and skills needed to own and manage oil palm plantations. More than $80 \%$ of the respondents who owned oil palm plantations were over 40 years old. Land ownership in these communities was hereditary as a result mostly the old owned plots of land. Except otherwise in the event of death of the father can the son inherit his father's land.

The level of education was basically primary school and junior high school drop outs. According to Ibitoye et al. (2011), good management of the oil palm plantations and even palm oil mills requires education to aid in transfer of improved practices in palm oil production. A majority of respondents were married. Unlike singles, the married people had their families as immediate source of labour, a major item for the maintenance and establishment of cash crop farms.

Farming details

Cocoa and oil palm are two common cash crops grown in this area, with oil palm cultivation being dominant over cocoa. Oil palm cultivation was considered for 
this study. Annual crops are usually intercropped on a majority of oil palm plantations in the study site. This is done only during the early stages of oil palm development (3-4 years) before the oil palm matures and starts producing. From the survey, of the 50 respondents questioned, $90 \%$ practiced intercropping on their oil palm plantations (of this percentage, $82 \%$ were owners of oil palm holdings who practiced intercropping with their families while $18 \%$ were owners of oil palm holdings who gave out their farmland to some other individuals to intercrop) and $10 \%$ did not. The agro-industry (CDC) in this area did not practice intercropping.

Favourite intercrop

After site preparation, lining, holing and planting of the oil palm seedling, a majority of the smallholder farmers intercropped annual food crops such as: plantain (Musa paradisiaca), banana (Musa acuminata), maize (Zea mays), groundnut (Arachis hypogaea), cassava (Manihot esculenta), cocoyam (Colocasia esculenta), egusi (Citrullus lanatus), garden huckleberry (Solanum melanocerasum), amaranthus (Amaranthus hybridus) and yam (Dioscorea sp.) on their farmlands. Food crops intercropped with oil palm had different planting and maturity dates (Table 2). In this area, the choice of food crops intercropped on oil palm plantations by the smallholders was based primarily on the immediate needs of the family, the needs of the local community and to a greater extent, the needs of the consumers they sell their produce to without them taking into consideration the compatibility of the said crop with oil palm. The planting of these annual crops by SH farmers was meant to first improve on their living conditions through the provision of food for subsistence as well as generate income through its sales to carter for other household problems such as education and health.

Not all food crops listed above were intercropped by each of these respondents on their different farmlands. The percentage distribution per SH respondent of annual crops on their different oil palm plantations in the study area are illustrated in Fig. 1.

All respondents intercropped with plantain on their oil palm holdings, with the least $(9 \%)$ intercropping with vegetable. Results from the survey showed that $27 \%$ of smallholder farmers practicing intercropping did intercrop with only plantain as the lone intercrop,
Table 1 Distribution of respondents by personal characteristics

\begin{tabular}{|c|c|}
\hline Variables & Percentage $(\%)$ \\
\hline \multicolumn{2}{|l|}{ Age in years } \\
\hline 70 and above & 4 \\
\hline $60-69$ & 16 \\
\hline $50-59$ & 26 \\
\hline $40-49$ & 38 \\
\hline $30-39$ & 14 \\
\hline \multirow[t]{2}{*}{ Below 29} & 2 \\
\hline & Mean $=48,9$ \\
\hline \multicolumn{2}{|l|}{ Gender } \\
\hline Male & 82 \\
\hline Female & 18 \\
\hline \multicolumn{2}{|c|}{ Level of education } \\
\hline University & 14 \\
\hline High school & 18 \\
\hline Secondary & 20 \\
\hline Primary & 48 \\
\hline \multicolumn{2}{|l|}{ Marital status } \\
\hline Single & 2 \\
\hline Married & 96 \\
\hline Widowed & 2 \\
\hline \multicolumn{2}{|l|}{ Household size } \\
\hline $11-15$ & 6 \\
\hline $6-10$ & 32 \\
\hline \multirow[t]{2}{*}{$1-5$} & 62 \\
\hline & Mean $=5,42$ \\
\hline
\end{tabular}

Source field survey report 2012

$22 \%$ of farmers intercropped with plantain and another crop (either maize, cocoyam, cassava, yams, groundnuts, egusi, or banana and $51 \%$ intercropped with plantain and two or more of the other crops.

Gender repartition

Intercropping on farmland is being practiced by 3 categories of individuals: The smallholder, workers on $\mathrm{SH}$ plantations and extended family members. Women were limited by land tenure and acquisition rights to own land, as well as capital and skills needed to own and manage the operations on oil palm plantations. That notwithstanding, more women were involved in the intercropping practice than men in the study site. $62 \%$ of those practicing intercropping were female, while the remainder were male. 
Table 2 Characterisation of food crops

\begin{tabular}{|c|c|c|c|c|}
\hline Annual crops & Scientific names & Planting periods/year & $\begin{array}{l}\text { Maturity } \\
\text { periods } \\
\text { (months) }\end{array}$ & $\begin{array}{l}\text { Number of } \\
\text { times of } \\
\text { harvesting/year }\end{array}$ \\
\hline Plantains & Musa paradisiaca & March & $10-12$ & 1 \\
\hline Yams & Dioscorea sp & March & 6 & 1 \\
\hline Cassava & Manihot esculenta & March & $11-12$ & 1 \\
\hline Cocoyam & Colocasia esculenta & March/April & 9 & 1 \\
\hline Maize & Zea mays & March/August & 3 & 2 \\
\hline Egusi & Citrullus lanatus & March & 3 & 1 \\
\hline Groundnut & Arachis hypogaea & March/August & 3 & 2 \\
\hline Banana & Musa acuminata & March & $10-12$ & 1 \\
\hline Garden huckleberry & Solanum melanocerasum & $\begin{array}{l}\text { Planting is done all year round except in July, } \\
\text { August and September because of heavy rains }\end{array}$ & 3 & 4 \\
\hline Bitterleaf & Vernonia amygdalina & $\begin{array}{l}\text { Planting is done all year round except in July, } \\
\text { August and September because of heavy rains }\end{array}$ & 3 & 4 \\
\hline Amaranthus & Amaranthus hybridus & $\begin{array}{l}\text { Planting is done all year round except in July, } \\
\text { August and September because of heavy rains }\end{array}$ & 3 & 4 \\
\hline
\end{tabular}

Source field survey report 2012

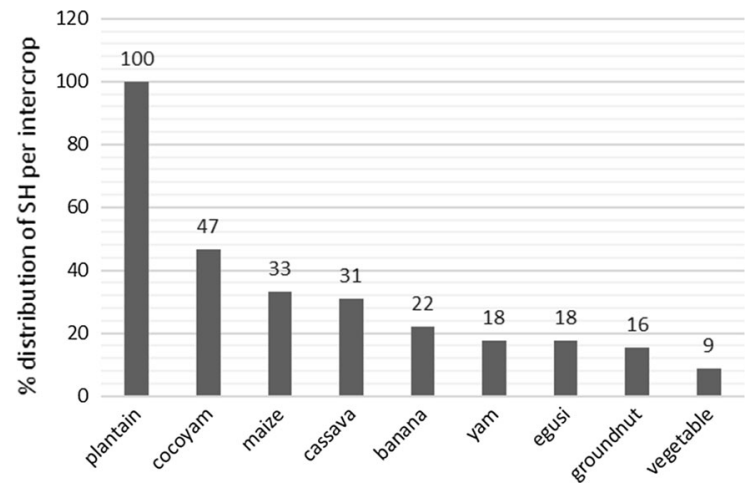

Fig. 1 Distribution of SH per intercrop oil palm plantations in the study area. Source field survey report 2012

\section{Reasons for intercropping}

Intercropping was practiced by smallholder farmers for varying reasons (Table 3):

Responses given exceed $100 \%$ because some respondents gave more than a single response.

\section{Reasons for not intercropping}

For smallholder farmers as well as for the agro-industry in the study site who did not practice intercropping, the reasons given were as follows: all CDC personnel questioned, said intercropping would result in poor plantation management; in addition to it being detrimental to oil palm yield at production stage. These they emphasized were of utmost importance to them as their primary objective as a company was getting good oil palm yields. SH farmers who did not practice intercropping said intercropping was detrimental at production stage, food crops attract more pests such as rodents and lastly some said that their plantations were further away from the village, an obstacle to regular visits.

Weed distribution and control

Whether intercropped or not, weed control (manual and or chemical) in oil palm plantations is unavoidable. Weeds if not attended to, can considerably affect the growth and yield of oil palm trees. Major weeds observed in the study site include: Chromolaena odorata (Achakasava), Panicum maximum (Guinea grass), Pueraria phaseoloides (Cover crop), Pennisetum purpureum (Elephant grass), Thomatoccocus danielli and Bambusa vulgaris (Indian bamboo). These weeds have adverse effects on the oil palm and also on intercrops. Weeds act as a hide out for pests, they are detrimental to oil palm growth, as they compete with the oil palm for nutrients, water and sunlight. They also cause difficulty in movement on the plantation. Majority (60\%) of respondents said "achakasava" was the most severe of all weeds 
Table 3 Reasons given for intercropping

Source field survey report 2012

\begin{tabular}{lll}
\hline Respondents & Reasons given & Percentage distribution (\%) \\
\hline Smallholder farmers & To raise income & 53 \\
& For subsistence & 44 \\
& To reduce farm maintenance cost & 40 \\
& To maximise land use & 27 \\
& To increase fertilising impact & 13 \\
& Good soil structure & 11 \\
\hline
\end{tabular}

Table 4 Frequency and cost of weeding by respondents

\begin{tabular}{|c|c|c|c|c|c|}
\hline Modality of weeding & & $\begin{array}{l}\text { Number of } \\
\text { respondents } \\
\text { involved in } \\
\text { the practice }\end{array}$ & $\begin{array}{l}\text { Number of } \\
\text { times/year }\end{array}$ & $\begin{array}{l}\text { Average weeding } \\
\text { cost per palm } \\
\text { (FCFA) }\end{array}$ & $\begin{array}{l}\text { Average weeding } \\
\text { cost per ha } \\
\text { (FCFA) }\end{array}$ \\
\hline \multirow[t]{2}{*}{ Manual weeding only } & Circle weeding & \multirow[t]{2}{*}{24} & $1-2$ & 87.5 & 12,513 \\
\hline & Slashing & & $2-5$ & 87.5 & 12,513 \\
\hline Herbicide application (Spraying) only & & 0 & 0 & 50 & 7150 \\
\hline \multirow{3}{*}{$\begin{array}{l}\text { Both manual weeding and herbicide } \\
\text { application }\end{array}$} & Manual weeding & \multirow[t]{3}{*}{26} & $2-5$ & \multirow[t]{3}{*}{225} & \multirow[t]{3}{*}{32,175} \\
\hline & Herbicide & & $1-3$ & & \\
\hline & application & & & & \\
\hline
\end{tabular}

Source field survey report 2012

** 1 ha $=143$ palms

present, followed by "Guinea grass" (44\%) with the least $(4 \%)$ being the "Indian bamboo".

Cost of weeding

Results from the survey showed that all respondents practiced weeding on their oil palm plantations. Of these, $48 \%$ practiced only manual weeding while $52 \%$ of respondents practiced both manual and chemical weeding. Table 4 gives a summary of the amount spent by respondents on manual and or chemical weeding on their farmlands.

Generally, the manual weeding (both slashing and circle weeding) costs on average 175 FCFA ( $€ 0.27)$ per palm depending on the severity of the weeds. Spraying of farms was mostly done by respondents themselves with help from their families. For those who paid for labour, it costs on average 50 FCFA (€0.08) to spray a palm.

\section{Cost of food crop seedlings}

Seedlings of food crops intercropped with oil palm were either purchased locally from other farmers in the
Table 5 Cost of different food crop seedlings

\begin{tabular}{llll}
\hline Food crop & $\begin{array}{l}\text { Average Cost } \\
\text { of seedling } \\
\text { (FCFA) }\end{array}$ & Selling unit & $\begin{array}{l}\text { Metric units } \\
\text { on average }(\mathrm{g})\end{array}$ \\
\hline Plantain & 75 & Per sucker & 1500 \\
Cocoyam & 1500 & Per basin & 3000 \\
Maize & 400 & Per sachet & 1000 \\
Cassava & $/$ & / & $/$ \\
Banana & 63 & Per sucker & 1500 \\
Yam & 80 & Per yam set & 50 \\
Egusi & 200 & Per glass & 100 \\
Groundnut & 150 & Per glass & 100 \\
Vegetable & 75 & Per bundle & 5
\end{tabular}

Source field survey report 2012

village or from the market. The average purchasing cost varied from 63 to 1500 FCFA depending on the food crop seedling to be purchased (Table 5). Of all the food crop seedlings, cassava cuttings were never bought because of their abundance after every harvest. Respondents took cuttings from their neighbours. 
Table 6 Mean annual farm expenditure per household (FCFA)/ha

\begin{tabular}{llllll}
\hline Farming technique & $\begin{array}{l}\text { Average number } \\
\text { of weeding } \\
\text { rounds per year }\end{array}$ & $\begin{array}{l}\text { Average cost } \\
\text { per weeding } \\
\text { (FCFA/ha) }\end{array}$ & $\begin{array}{l}\text { Mean annual } \\
\text { weeding cost } \\
\text { (FCFA/ha/yr.) }\end{array}$ & $\begin{array}{l}\text { Cost of food } \\
\text { crop seedlings } \\
\text { (FCFA/ha) }\end{array}$ \\
\hline Intercropping & 3 & 32,175 & 96,525 & 49,769 & 0 \\
No intercropping & 5 & 32,175 & 160,875 & 0 \\
\hline
\end{tabular}

Source field survey report 2012

Table 7 Mean annual production per hectare per $\mathrm{HH}$

\begin{tabular}{|c|c|c|c|c|c|c|c|c|c|}
\hline & \multicolumn{9}{|c|}{ Annual food crops } \\
\hline & Plantain & Banana & Cocoyam & Yam & Egusi & Groundnut & Maize & Vegetable & Cassava \\
\hline $\begin{array}{l}\text { Number of } \mathrm{HH} \text { involved } \\
\text { in intercrop cultivation }\end{array}$ & 33 & 5 & 8 & 4 & 6 & 6 & 8 & 3 & 5 \\
\hline $\begin{array}{l}\text { Annual production/ } \\
\mathrm{HH} / \mathrm{ha}\end{array}$ & $\begin{array}{l}4673.44 \\
\text { bunches }\end{array}$ & $\begin{array}{l}64.5 \\
\text { bunches }\end{array}$ & $\begin{array}{l}63.5 \\
\text { buckets }\end{array}$ & $\begin{array}{l}26.6 \\
\text { heaps }\end{array}$ & $\begin{array}{l}64.38 \\
\text { buckets }\end{array}$ & $\begin{array}{l}26.64 \\
\text { buckets }\end{array}$ & $\begin{array}{l}103.7 \\
\text { buckets }\end{array}$ & $\begin{array}{l}154 \\
\text { bundles }\end{array}$ & $\begin{array}{l}27.3 \\
\text { basins }\end{array}$ \\
\hline $\begin{array}{l}\text { Mean annual production/ } \\
\mathrm{HH} / \mathrm{ha}\end{array}$ & $\begin{array}{l}141.62 \\
\text { bunches }\end{array}$ & $\begin{array}{l}12.9 \\
\text { bunches }\end{array}$ & $\begin{array}{l}7.94 \\
\text { buckets }\end{array}$ & $\begin{array}{l}6.65 \\
\text { heaps }\end{array}$ & $\begin{array}{l}10.73 \\
\text { buckets }\end{array}$ & $\begin{array}{l}4.41 \\
\text { buckets }\end{array}$ & $\begin{array}{l}12.96 \\
\text { buckets }\end{array}$ & $\begin{array}{l}51.3 \\
\text { bundles }\end{array}$ & $\begin{array}{l}5.46 \\
\text { basins }\end{array}$ \\
\hline
\end{tabular}

Not all smallholder oil palm farmers intercropped on their farm land. Therefore, cost of food crop purchase was incurred only by those who intercropped. In addition, the cost of weeding annually varied between smallholder farmers who intercropped as opposed to those who did not practice intercropping. This is so because the number of times weeding was carried out when using the two different farming techniques differed (Table 6).

From Table 6, a mean of 146,294 FCFA (€223.02) is spent annually in setting up and maintaining intercropped farmlands. Of this amount 96,525 FCFA/ $€ 145.63$ (more than $50 \%$ of the total amount) is spent per hectare on both manual and chemical weeding respectively while the remaining 49,769 FCFA (€75.87) is spent for food crops seedlings purchase. The smallholder who gives out his plot to another individual to intercrop spends less $(96,525$ FCFA) for weed control. On the other hand an annual mean of 160,875 FCFA ( $€ 245.25)$ is spent on weeding per hectare on farmland without intercropping. This amount is greater than the former as a result of the presence of more weeds which necessitates more weeding. A smallholder who does not practice intercropping therefore incurs a higher cost.
Harvesting and yield

The different annual food crops intercropped with oil palm are either consumed at home or sold at the local markets. Food crop prices fluctuate depending on their availability in the local market (prices increase when crop produce is scarce and vice versa). From the data collected in the study area, the annual quantity per ha of the different intercrops for each SH was calculated. This was used to obtain the annual production per $\mathrm{HH}$ per ha (Table 7), the annual yield per ha for the different food crops in the different households (Table 8).

A mean of 851,140 FCFA $(€ 1,297.55)$ was earned annually per household per ha from the total food crop production. Yams are considered to be the most valued food crop in terms of revenue as they contribute to over $50 \%$ of the total income from sales of all intercropped food crops.

The return to labour from intercropping was obtained using the formula: $\mathrm{RL}=\mathrm{H}-(\mathrm{S}+\mathrm{W})$. Where $\mathrm{H}$, is the total revenue from sales of food crops, $\mathrm{S}$, cost of food crops seedlings purchased and $\mathrm{W}$, is the total weeding costs (both manual and chemical weeding) of farm. 
Table 8 Mean annual income from food crop production per ha per $\mathrm{HH}$

\begin{tabular}{|c|c|c|c|c|c|c|}
\hline Food crop & $\begin{array}{l}\text { Average selling } \\
\text { price (FCFA) }\end{array}$ & $\begin{array}{l}\text { Selling } \\
\text { units }\end{array}$ & $\begin{array}{l}\text { Mean annual } \\
\text { production/ha/HH }\end{array}$ & $\begin{array}{l}\text { Mean annual income } \\
\text { per ha/HH (FCFA) }\end{array}$ & $\begin{array}{l}\text { Percentage } \\
\text { consumed }(\%)\end{array}$ & $\begin{array}{l}\text { Percentage } \\
\text { sold }(\%)\end{array}$ \\
\hline Yam & 55,000 & Heap & 6.65 & 365,750 & 20 & 80 \\
\hline Plantain & 2000 & Bunch & 141.62 & 283,240 & 60 & 40 \\
\hline Cassava & 10,000 & Bag & 5.46 & 54,600 & 40 & 60 \\
\hline Maize & 3500 & Bucket & 12.96 & 45,360 & 40 & 60 \\
\hline Egusi & 4000 & Bucket & 10.73 & 42,920 & 40 & 60 \\
\hline Cocoyam & 3250 & Bucket & 7.94 & 25,805 & 60 & 40 \\
\hline Groundnut & 3500 & Bucket & 4.41 & 15,435 & 60 & 40 \\
\hline Banana & 1000 & Bunch & 12.9 & 12,900 & 60 & 40 \\
\hline Vegetable & 100 & Bundle & 51.3 & 51,300 & 80 & 20 \\
\hline
\end{tabular}

Source field survey report 2012

Table 9 Mean annual household return to labour (wage) from intercrops

\begin{tabular}{lllll}
\hline Those involved in oil palm cultivation & $\begin{array}{l}\text { Mean annual household income } \\
\text { from total food crop production } \\
\text { per ha (FCFA) }\end{array}$ & $\begin{array}{l}\text { Mean annual farm expenditure } \\
\text { (food crop seedlings and } \\
\text { weeding cost) per ha/FCFA }\end{array}$ & $\begin{array}{l}\text { Mean annual return } \\
\text { to labour (FCFA) }\end{array}$ \\
\hline Smallholders & Intercropping & $851,140(€ 1,297.55)$ & $146,294(€ 223.02)$ & $704,846(€ 1,074.53)$ \\
& No intercropping & 0 & $160,875(€ 245.25)$ & $160,875(€ 245.25)$ \\
\hline
\end{tabular}

Source field survey report 2012

A mean of 704,846 FCFA $(€ 1,074.53)$ was therefore gained as return to labour annually from intercrop farming (Table 9). While for smallholders who do not practice intercropping, nothing is obtained annually as net income because of the absence of intercrops on their oil palm plantations, yet more money is allocated $(160,875$ FCFA/€245.25) annually for weeding.

\section{Discussion}

Oil palm and the intercropping practice

Results from the findings showed that, oil palm was rarely being planted as a monocrop $(10 \%)$ by $\mathrm{SH}$ farmers in the study site but it was being intercropped with annual food crops during the first three to four years (corresponding to the immature stage) of oil palm. This was previously reported by Cheyns and Rafflegeau (2005), who stated that "in Cameroon, whether on family farms or on medium-sized farming enterprises, food crops are usually grown in most immature oil palm plots, either over the entire plot or in part of it".
In the study area, no special considerations (such as; the choice of crops to be planted, spatial arrangements and planting time of intercrops, etc.) were put in place by farmers practicing intercropping. According to Diemer et al. (2004); Machado (2009); (Agrobrief No 4 2011), this can be seen as an inappropriate practice as they advised that each crop in an intercropping system should have adequate space to maximize interaction and minimize competition between crops by paying attention on:

- the specific local conditions (climate); be it humid, sub-humid, semi-arid and savannah determines the kind of crops to be planted in such an area that will better utilize the available natural resources;

- the choice of the crops; crops chosen should be such that can be locally grown and whose seeds and other planting materials can be obtained from other farmers, at local markets or from specialized seed producers. It is advisable to consider leguminous crops as they fix nitrogen and help improve soil fertility and soil structure;

- the arrangement in space and time; crops can be sown in rows, strips, mixed or otherwise. The 
sequence of the type of intercrops with the palms should also be taken into consideration.

- planting and maturity dates of the different crops; it is advantageous if the different intercrops have different maturity dates, with different times of peak demand for nutrients, water and sunlight, thereby reducing competition. Another aspect of the timing of the sowing dates of nitrogen-fixing legumes is the release of nitrogen from the crop remnants after harvest. Adaptation in the planting dates of the different plants in an intercrop can help to reduce competition and to maximize yields;

- the plant density; when planting, the root architecture of both intercrop and the palms should be taken into consideration by leaving adequate space between crops. The more closely spaced plants are, the higher the density and vice versa.

Profitability of intercropping

The benefits of intercropping to farmers are economic, social or agro-ecological.

As shown in the results, intercropping generates income to people of all social class and age groups. Although women were limited by capital and land tenure and acquisition rights to own land, intercropping was particularly attractive to them because it involves minimal inputs in the form of income and labour which women can provide. Intercropping is also beneficial to women in that the income obtained is normally used for general household upkeep and improved nutrition of the family. From the study, intercropping was mostly done for subsistence and as a means to raise income because of the delayed income earning of oil palm which is a major setback to oil palm cultivation. This affirms the findings of Tonye et al. (2004) which showed that, though the oil palm agroforest is labour demanding, its high profit and return to labour will probably make the farmers adopt the system faster than the low labour but no earlyincome-generating oil palm monocrops.

Intercropping also results in social benefits. Income from intercrops results in improved social cohesion at the family levels (both immediate and extended). Family members especially those living in the same household though not directly involved in the intercropping practice benefit from intercrop income through the provision of basic amenities such as school fees and hospital bills amongst others, savings are also made in tontines from these incomes for future use before the palms mature. Through intercropping, the relationship between labourers and SH farmers are strengthen as they not only get income from monthly pay but also get subsistence and income from the sale of crops they intercropped on their employers plantations. To the SH themselves, who own big farms with many labourers working for them, this adds up to their social status through the respect they gain from everyone in their communities.

Lastly, intercropping is important as it helps in weed control. Results from data collected showed that smallholders not practicing intercropping incurred a higher weeding cost when compared to those who practiced intercropping. This was similar to the findings reported by Liebman and Dyck (1993); Tonye et al. (2004).

Impact of intercropping on future palm oil yield

This study was limiting in that during the time of data collection, the palms were still at their immature stage. And because of this timeframe, we were not able to assess the negative impact on the future yields of oil palm. However, according to some existing studies by Rafflegeau et al. 2010, it was pointed out that, the presence of food crops on oil palm plantations at the immature stage resulted in Nitrogen $(\mathrm{N})$ and Potassium $(\mathrm{K})$ deficiencies which persist even when the plantations reach the production stage especially without appropriate annual fertilization. $\mathrm{N}$ is very important as it increases leaf area and the net assimilation rate thus resulting in increased biomass production (Breure 1982). Another study by Okyere et al. (2014), showed there exist a difference in the yield of oil palm from oil palm monocrop compared to oil palm intercropped with food crops but this difference was not significant for that particular study because a strict cropping system was developed and followed.

That notwithstanding, farmers do not reason in terms of the profitability of a single crop. The crops intercropped with oil palm during the first 4 years enable farmers to diversify their income, benefit from a worthwhile labor, or benefit from inputs provided by the intercrops especially leguminous crops (Cheyns and Rafflegeau 2005). The study therefore, does not refute the fact that there will be no negative impact 
resulting from intercropping, but if pre-emptive measures are put in place as already mentioned above, it will go a long way to sustain the benefits of intercrops and oil palm.

Lastly, regarding the negative impact of intercrops on future oil palm yields, it would be important to carry out yield measurements as soon as the palms enter into production for a number of years (say 5-10 years) before we can say with some precision whether intercropping possess a negative impact on the yield of oil palm. This can be done through the selection of plots with the same age, biophysical and management conditions when collecting fresh fruit bunch (FFB) yields from intercropped and nonintercropped plots.

\section{Conclusion}

]Though the intercropping of oil palm with food crops has a negative impact on the yield of the oil palm, most smallholders still practice intercropping for subsistence and to improve on their income levels. This intercropping also helps to reduce the weeding cost of the oil palm plantation, and helps to maximize land use as smallholders are less tempted to open forest land to plant food crops. In terms of the intercrops, smallholders in the study site cultivate more plantains, cocoyam, maize, cassava etc. as compared to other food crops such as beans, groundnuts etc., probably because of cultural values. The most valued food crops in cash were yam, plantain, cassava in decreasing order of importance. The sources of their planting material came either from $\mathrm{SH}$ farmland, local market or from the agro-industrial company situated in the area (CDC and PAMOL).

On the other hand the nearby agro-industrial plantation was not practicing intercropping as their main goal as a business enterprise was to get maximum benefit from oil palm yields.

There is therefore a knowledge gap which needs to be bridged for the smallholders in this area on the quality of planting material for the intercrop, crops to promote and crops to avoid, best intercropping techniques, and best management practices for the main crop, oil palm. There is also the need to study the effects of different intercropping models on the yields of the oil palm, and the need to see how intercropping could be practiced when palms have entered their production stage.
Acknowledgments The authors are grateful to the CGIAR Research Program on Forests, Trees and Agroforestry (http:// www.cifor.org/forests-trees-agroforestry) for their financial support and also to all smallholder farmers and the CDC personnel who devoted their time in answering our questions.

Open Access This article is distributed under the terms of the Creative Commons Attribution 4.0 International License (http:// creativecommons.org/licenses/by/4.0/), which permits unrestricted use, distribution, and reproduction in any medium, provided you give appropriate credit to the original author(s) and the source, provide a link to the Creative Commons license, and indicate if changes were made.

\section{References}

Agrobrief No 4 (2011) Intercropping of annual food crops. Agromisa Foundation p. 10

Amoah FM, Nuertey BN, Baidoo-addo K, Oppong FK, Oseibonsu K, Asamoah TBO (1995) Underplanting oil palm with cocoa in Ghana. Agrofor Syst 30:289-299

Bakoume C, Mahbob BA (2006) Cameroon offers palm oil potential. Oils fats int 3:25-26

Bakoume C, Jannot C, Rafflegeau S, Ndigui B, Weise S (2002) Revue du secteur rural: Etudes complémentairessur le reliance de filières hévéa et palmier à huile. Rapport palmier, IRAD/CIRAD/IITA 80 p

Better Crops International (1999) Potash \& Phosphate Institute/ Potash \& Phosphate Institute of Canada. 13(1): 56

Brainard DC, Bellinder RR (2004) Weed suppression in a broccoli-winter rye intercropping system. Weed Sci 52(2):281-290

Breure CJ (1982) Factors affecting yield and growth of oil palm teneras in West New Britain. In: Pushparajah E, Chew PS (eds) The oil palm in agriculture in the eighties., pp 109-130

Cheyns E, Rafflegeau S (2005) Family agriculture and the sustainable development issue: possible approaches from the African oil palm sector: the example of Ivory Coast and Cameroon. Oléagineux Corps Gras Lipides 12:111-120

Diemer P, Chinchilla C, Griffee P (2004) Small holder oil palm manual. Food and Agriculture Organisation of the United Nations. Rome, Italy

Ibitoye OO, Akinsorotan AO, Meludu NT, Ibitoye BO (2011) Factors affecting oil palm production in Ondo State of Nigeria. J Agric Soc Res 11(1):97-105

Jacquemard JC (2012) Le palmier à huile, Editions Quae

Kwasi P (2002) Small-scale palm oil processing in Africa. Food and Agriculture Organisation of the United Nations, Rome

Liebman M, Dyck E (1993) Crop rotation and intercropping strategies for weed management. Ecol Appl 3(1):92-122

Nair PR (1993). An introduction to agroforestry. Springer Science \& Business Media

Ngando EGF, Mpondo MEA, Dikotto EEL, Koona P (2011) Assessment of the quality of crude palm oil from smallholders in Cameroon. J Stored Products Post-Harvest Res 2(3):52-58

Nkongho Raymond N, Feintrenie Laurène, Levang Patrice (2014) Strengths and weaknesses of the oil palm 
smallholder sector in Cameroon. Oil Crops Supply Chain Africa 21(2):D208

Okyere SA, Danso F, Larbi E, Danso I (2014) Residual effect of intercropping on the yield and productivity of oil palm. Int J Plant Soil Sci 3(7):854-862

Opeke LK (1987) Tropical tree crops. Published by Woye and Sons (Nig) Limited. Ilorin, p. 327

Pridham JC, Entz MH (2008) Intercropping spring wheat with cereal grains, legumes, and oilseeds fails to improve productivity under organic management. Agronomy J 100(5):1436-1442

Rafflegeau S, Ndigui B (2001) Synthèse d'enquêtes agroéconomiques réalisées dans une centaine d'exploitations élaeicoles du sud du Cameroun, IRAD—Station de la Dibamba, p 70

Rafflegeau S, Michel-Dounias I, Tailliez B, Ndigui B, Papy F (2010) Unexpected N and K nutrition diagnosis in oil palm smallholdings using references of high-yielding industrial plantations. Agronomy Sustain Dev 30(4):777-787

San Cortés R (2003) Terminology used in "family agriculture systems" research. CIRAD-TERA 4:20

Tonye J, Bayomock LA, Zoa JM (2004) Development of oil palm-based agroforest at the slash-and-burn agriculture project zone of Cameroon: agronomy and economics of the establishment phase. Cameroon J Agric Sci 1(1):42-45

Vermeulen S, Goad N (2006) Towards better practice in smallholder palm oil production. International Institute for Environment and Development, p. 57

Zen Z, Barlow C, Gondowarsito R (2005) Oil palm in Indonesian socioeconomic improvement: a review of options. Working Paper in Trade and Economics 11. Economics, Research School of Pacific and Asian Studies 